\title{
Interaction among bacterioplankton and macrophytes in shallow lakes with high macrophyte cover
}

\author{
Nóra Szabó-Tugyi ${ }^{1} \cdot$ Viktor R. Tóth $^{1}$ (i)
}

Received: 17 January 2020 / Accepted: 27 August 2020 / Published online: 5 September 2020

(c) The Author(s) 2020

\begin{abstract}
Growth of submerged and emergent macrophytes was studied together with heterotrophic bacterioplankton abundance and production in two Hungarian shallow lakes with dominant macrophyte covers. It was expected that bacterioplankton numbers and activity would have an effect on macrophyte biomass accumulation. Bacterial production and abundance showed a strong seasonal pattern with maximum in the warmest months (July, August). It was found that macrophyte biomass increased with heterotrophic bacterial production and abundance up to $5.6 \mu \mathrm{g} \mathrm{C} 1^{-1} \mathrm{~h}^{-1}$ and $5.30 * 10^{6}$ cells, respectively, while over that value was negatively associated with macrophyte growth. It was also shown that the relationship between heterotrophic bacteria and macrophytes also varied seasonally, showing a multifaceted relationship. It was demonstrated that macrophytes are not only the most significant carbon and energy source for the bacteria in shallow, macrophyte-dominated lakes, but are also competing organisms that could be supressed by excessive bacterial activity. These findings could help better understand the interaction between macrophytes and bacterioplankton, and assist wetland managers in quantifying what may be a primary cause of reed die-back.
\end{abstract}

Keywords Bacterioplankton $\cdot$ Macrophytes $\cdot$ Sctivity $\cdot$ Abundance $\cdot$ Litter $\cdot$ Biomass accumulation

\section{Introduction}

Although wetlands and littoral zones cover less than 7\% of the Earth's land surface, they are the most important natural carbon reserves (Reddy and DeLaune 2008) one of the most productive zones globally, as well as sites of intense decomposition, especially of organic carbon (Richey et al. 2002; Duarte and Prairie 2005). These areas are therefore crucial, not only to the freshwater water bodies with which they are associated, but also to connected terrestrial landscapes (Odum 1956; Schindler and Scheuerell 2002).

Macrophytes simultaneously integrate the effects of and changes to several environmental factors (Lacoul and Freedman 2006). Rooted macrophytes, via their roots and

Electronic supplementary material The online version of this article (https://doi.org/10.1007/s00027-020-00753-9) contains supplementary material, which is available to authorized users.

Viktor R. Tóth

toth.viktor@okologia.mta.hu

1 Centre for Ecological Research, Balaton Limnological Institute, Tihany, Hungary rhizomes, are affected by the sediment in a wide variety of ways (Barko et al. 1991; Armstrong et al. 19962006). Some such interactions are universal, while some are specific to the aquatic environment. Plant growth is directly affected by nutrient availability and uptake (Barko and Smart 1986; Lacoul and Freedman 2006; Tóth et al. 2017), and the growth and distribution of macrophytes are also affected by the different chemical and physical characteristics of the sediment (Armstrong and Armstrong 1999; Koch 2001; Tóth 2016). The organic matter content of the sediment influences not only the growth and distribution of individual plants (Barko and Smart 1983; Koch 2001), but also the species composition of the community, and even successional processes within the ecosystem (Carpenter 1981).

The organic carbon of wetlands and littoral zones is an important part of aquatic ecosystem metabolism (Wetzel 1995) and both periphytic and planktonic heterotrophic bacteria assimilate a large portion of it for both energetic and structural purposes (Azam et al. 1983, 1994; Findlay et al. 1986). In small, shallow lakes with large littoral zones, the importance of autochthonous dissolved organic matter originating from macrophytes is high (Jonsson et al. 2001; Cole et al. 2002), moreover higher heterotrophic bacterioplankton 
activities were reported from lakes with high macrophyte cover (Reitner et al. 1999; Jeppesen et al. 2002; Rooney and Kalff 2003). The distribution of dead plant biomass (litter) can therefore directly and indirectly influence microorganisms and, as a result, environmental conditions (Tranvik et al. 2009).

Macrophytes directly affect their environment. Among other things, the availability of litter increases the amount of organisms participating in the decomposition of macrophyte biomass (Findlay et al. 1986; Reitner et al. 1999; Jeppesen et al. 2002; Rooney and Kalff 2003), which consequently influences larger ecosystem processes. While it is believed that each lake has a specific set of bacteria typical to the given lake (Lindström 2000; Yannarell and Triplett 2005; Jones et al. 2009), the data also suggest that these specific or characteristic sets of bacteria come from bacterial groups with global distributions (Lindström et al. 2005; Schauer et al. 2005; Sommaruga and Casamayor 2009). These bacteria, which contribute to litter decomposition in freshwater lakes, play an outstanding role in the regulation and directing the processes within the aquatic ecosystem, and affect the water quality of the whole lake (Newton et al. 2011). The amount of nutrients ( $\mathrm{N}$ and $\mathrm{P}$ ) available determines the nature of the process of respiration and the associated terminal electron acceptor compound, and consequently the oxidation-reduction conditions of the environment: high carbon and low $\mathrm{N}$ and $\mathrm{P}$ conditions promote anaerobic processes, such as methanogenesis, sometimes resulting in extremely low oxidation-reduction potential (Laanbroek 1990; Reddy and DeLaune 2008; Middelburg and Levin 2009). Thus, bacterial activity also significantly affect the macrovegetation of wetlands and littoral zones via the decomposition of C.

Whereas the majority of studies suggest direct bacterial dependence on macrophytes (Findlay et al. 1986; Reitner et al. 1999; Jeppesen et al. 2002; Rooney and Kalff 2003), very little is known about the effects of bacterioplankton on macrophyte growth and biomass accumulation. In our work, we analysed the growth and biomass accumulation of submerged and emerged macrophyte stands in two shallow Hungarian lakes in relation to the amount and activity of bacterioplankton. We hypothesised (i) that bacterioplankton production affects the growth and biomass accumulation of macrophytes, and (ii) that the amount of non-autotrophic bacteria affects the growth of macrophytes and biomass accumulation.

\section{Materials and methods}

\section{Site description}

Lake Fertő (Neusiedler See) (Supplementary Fig. 1a) is a $315 \mathrm{~km}^{2}$ soda lake situated on the border between Hungary and Austria. It is shallow ( $<1.4 \mathrm{~m}$ depth), turbulent, $36 \mathrm{~km}$ long, and $12 \mathrm{~km}$ wide at the widest part of the lake. While more than $55 \%$ of Lake Fertó is covered by macrovegetation, $64 \mathrm{~km}^{2}(\sim 85 \%)$ of the Hungarian part of the lake is covered by emergent macrophytes, predominantly Phragmites australis (Cav.) Trin. ex Steud. (Supplementary Fig. 1a). Beginning from the early $1980 \mathrm{~s}$, reed stands in the Hungarian part of Lake Fertő were affected by die-back. Approximately $30 \%$ of the Hungarian stands are now at different stages of the related degradation (Márkus et al. 2008; Márkus and Király 2012), while on the Austrian side of the lake, reed stand deterioration is at $\sim 10 \%$ (Schmidt and Csaplovics 2010).

Lake Kolon is a $\sim 6 \mathrm{~km}$ long, $27.3 \mathrm{~km}^{2}$ lake that is almost fully covered with macrovegetation, with occasional openings at the surface, located in the middle of Hungary, in the Danube-Tisza interfluve (Supplementary Fig. 1b). The lake receives water from the discharge of a short local flow system on its eastern side and recharges another short gravity system to the west. The dominant chemical type of the lake is $\mathrm{Ca}-\mathrm{Mg}$-bicarbonate (Mádl-Szőnyi and Tóth 2009), and its average water level is less than $2 \mathrm{~m}$ depth.

Two areas were chosen for sampling in Lake Fertô and two in Lake Kolon (Supplementary Fig. 1). In the southern part of the Lake Fertó, we used a sampling site $\left(47^{\circ} 38^{\prime} 57.41^{\prime \prime} \mathrm{N}, 16^{\circ} 43^{\prime} 44.81^{\prime \prime} \mathrm{E}\right)$ within a reed stand and a sampling site in a relatively large $\left(0.03 \mathrm{~km}^{2}\right)$ opening covered with submerged macrophyte $\left(47^{\circ} 39^{\prime} 51.61^{\prime \prime} \mathrm{N}\right.$, $16^{\circ} 42^{\prime} 53.33$ "E). In Lake Kolon a sampling site within the reed stand $\left(46^{\circ} 48^{\prime} 5.67^{\prime \prime} \mathrm{N}, 19^{\circ} 20^{\prime} 9.65^{\prime \prime} \mathrm{E}\right)$ and a site in a relatively large $\left(0.05 \mathrm{~km}^{2}\right)$ opening covered with submerged macrophyte $\left(46^{\circ} 46^{\prime} 24.70^{\prime \prime} \mathrm{N}, 19^{\circ} 20^{\prime} 24.79^{\prime \prime} \mathrm{E}\right)$ were selected. Biomass and water sampling was performed on a monthly basis in 2015 and 2016.

\section{Plant morphological measurements}

Macrophytes from both emergent and submerged macrophyte-dominated sites were sampled (repeatedly harvested from areas near the plots) throughout the vegetation period (April-October) at least once a month. Due to plant high heterogeneity at sites, plants from 4 to 5 random $0.25 \mathrm{~m}^{2}$ quadrants were collected, and samples were pooled, and considered a single observation. Submerged macrophytes were sorted into species, oven dried for a week at $65{ }^{\circ} \mathrm{C}$ and weighed, while emergent macrophytes were cut at the water level, sorted into species, the green and dry parts were oven dried separately for a week at $65^{\circ} \mathrm{C}$ and weighed separately. Biometric measurements were performed only on green Phragmites plants: plant height was determined as the length from the cut surface to the tip of the top leaf or seed head, the diameter in the middle of the most basal internode of each cut reed stem was measured to the nearest $0.1 \mathrm{~mm}$ with a vernier calliper, and both green and dry leaves, as 
well as the number of nodes of each plant, were counted. Stem, leaves, and seed heads of green plants were weighed separately after drying.

\section{Water sample analyses}

Total suspended matter (TSM) was measured gravimetrically after filtering the water through a previously dried and preweighed GF-5 fibreglass filter (nominal pore size $=0.4 \mu \mathrm{m}$ ), drying for $2 \mathrm{~h}$ at $105^{\circ} \mathrm{C}$, then weighing again and subtracting the filter weight from the total weight. TSM concentration was calculated based on the predetermined volume of the filtered sample. The concentration of coloured dissolved organic matter (CDOM) was measured spectrophotometrically at $440 \mathrm{~nm}$ (Hitachi, U-2900) after filtering the water through a cellulose acetate filter (pore size $0.45 \mu \mathrm{m}$ ), and was expressed as $\mathrm{Pt}$ (platina) units ( $\mathrm{mg} \mathrm{Pt}^{-1}$ ) (Cuthbert and Del Giorgio 1992). Nitrogen forms (ammonium, nitrate, and urea) (Newell et al. 1967; Elliott and Porter 1971; Mackereth et al. 1978), total phosphorus (TP) (Menzel and Corwin 1965) and total soluble phosphorus (TSP) (Gales et al. 1966) were determined. Chlorophyll- $a$ of the water column was determined from freshly collected samples. $1 \mathrm{~L}$ of sampled water was filtered through Whatman GF-5 filter papers, and pigments were analysed following extraction in $60{ }^{\circ} \mathrm{C}$ methanol and clarification by centrifugation $(10000 \mathrm{rpm}$ for 10 min) (Iwamura et al. 1970).

\section{Bacterial production and count measurements}

Bacterial production (BP) was measured using the radiolabelled leucine L-[4,5- ${ }^{3} \mathrm{~h}$ ] incorporation method (Kirchman et al. 1985; Gasol 1999). Mixed leucine solution (radiolabelled leucine:normal leucine $=1: 10$ ) was added to fresh water samples in situ at varying concentrations $(20 \mathrm{nM}$, $40 \mathrm{nM}, 70 \mathrm{nM}, 100 \mathrm{nM}$, and $200 \mathrm{nM}$ ) in triplicate. Incubation was performed at actual lake temperatures measured during sampling. The reaction was stopped with $50 \mathrm{v} / \mathrm{v} \%$ trichloroacetic acid (TCA). TCA-killed controls were also used to correct for the abiotic uptake of labelled leucine.

Unincorporated radiolabelled leucine was separated by centrifugation. A scintillation cocktail was added to our pellet and, after one day, we measured the disintegration per minute of samples by TRI-CARB 2100TR Liqiud Scintillation Analyzer. From this, we calculated the leucine uptake rate (Kirchman et al. 1985) and the bacterial biomass production (Simon and Azam 1989).

Total bacteria were detected by DAPI (4',6-diamidino2 -phenylindole)-staining (Porter and Feig 1980). Formaldehyde-fixed water samples were collected onto $0.2 \mu \mathrm{m}$ polycarbonate filters, cells were identified under ultraviolet (350-450 nm) excitation with a colour camera (Olympus DP71) on an Olympus BX51 microscope. Heterotrophic bacterial abundance, i.e. bacterial abundance (BA) was calculated by subtracting the abundance of autotrophic picoplankton (data not shown) from the total number of bacteria. The abundance of total bacteria was determined using YABBA-2011 (Yet Another Bacterial Biovolume Algorithm - http://www.technobiology.ch) software (Zeder et al. 2011), while heterotrophic bacterial abundance was calculated by subtracting autotrophic picoplankton types (data not shown) from the total bacteria number.

\section{Oxidation-reduction potential and oxygen content measurement}

The oxidation-reduction potential (ORP) of the sediment was determined at each sampling point every sampling date. ORP was measured with a multisensory probe containing 5 platinum coils mounted $10 \mathrm{~cm}$ apart on a $50 \mathrm{~cm}$ long fiberglass reinforced epoxy tube and attached to a 1-m long aluminium probe (Paleo Terra, Netherland). ORP data were registered with a custom-built voltmeter recorder (Paleo Terra, Netherland) against a saturated $\mathrm{Ag} / \mathrm{AgCl}$ reference electrode and related to the standard hydrogen electrode.

Water oxygen content was measured in situ in every $25 \mathrm{~cm}$ of the water column using HQ30d multimeter with a LDO101 DO Probe (Hach, USA).

\section{Statistical analyses}

A two-way ANOVA was used to determine differences in abiotic and biotic factors with site (Lake Kolon and Lake Fertô) and macrophyte type (emergent and submerged) as independent variables, while measured parameters as dependent. Time-, site-, and habitat-specific differences were analysed by 3-way ANOVAs following data normalisation, where time, site (Lake Kolon and Lake Fertó) and macrophyte type (emergent and submerged) were as independent variables, while measured parameters as dependent. All data were graphed and statistically analysed (linear or non-linear regression) using SigmaPlot 12.5. We used generalized additive models (gam in $\mathrm{R}$ ) to evaluate associations among water temperature, macrophytes and bacteria.

\section{Results}

In Lake Fertő, within the studied opening dominated by submerged macrophytes Najas marina L., Utricularia vulgaris L., Hydrocharis morsus-ranae L., and Ranunculus circinatus L. were observed, although the vast majority of the collected biomass (>99\%) was N. marina. Submerged plants were of a detected in June, and, by the end of August, biomass peaked at $585 \mathrm{~g}$ [dry mass] $\mathrm{m}^{-2}$ (Fig. 1). The emergent site in Lake Fertő was dominated by Phragmites (Supplementary 


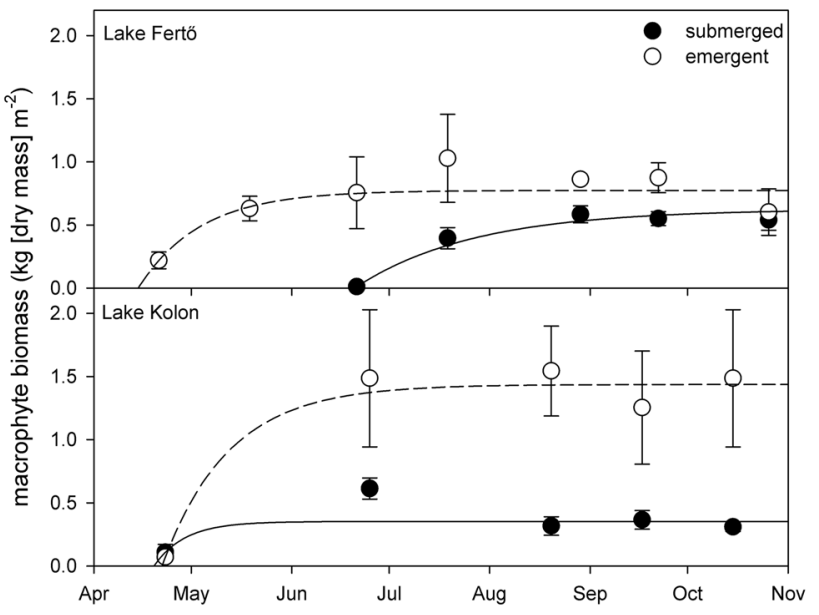

Fig. 1 Biomass accumulation of submerged (black circles) and emergent (white circles) macrophytes in Lake Fertő and Lake Kolon

Fig. 1a). Reed biomass accumulation began at the end of April and maximum biomass $\left(1030 \pm 350 \mathrm{~g}\right.$ [dry mass] $\left.\mathrm{m}^{-2}\right)$ was reached at the end of July (Fig. 1). In the process of senescence, biomass gradually decreased to $600 \pm 180 \mathrm{~g}$ [dry mass] $\mathrm{m}^{-2}$ by the end of October (Fig. 1).

In Lake Kolon (Supplementary Fig. 1b), within the submerged macrophyte-dominated opening Nymphaea alba L., Nuphar lutea L. Sm, Ranunculus circinatus L., Utricularia vulgaris L., Hydrocharis morsus-ranae L., Stratiotes alloides L., and Ceratophyllum demersum $L$ were found. These species were unevenly distributed; in the sampling area at the centre of the opening, only Nymphaea and Nuphar were dominant. By the end of April, plants were visible at the site, while their biomass peaked at the end of June, with $612 \pm 83 \mathrm{~g}$ [dry mass] $\mathrm{m}^{-2}$. By the end of summer, biomass was approximately $300 \mathrm{~g}$ [dry mass] $\mathrm{m}^{-2}$ (Fig. 1).

The emergent macrophyte-dominated area of Lake Kolon (Supplementary Fig. 1b) consisted of Phragmites ( $>74 \%$ of all biomass), Typha latifolia L., Carex sp., Nymphaea alba, Ceratophyllum demersum, Utricularia vulgaris. At the end of April, $70 \pm 18 \mathrm{~g}$ [dry mass] $\mathrm{m}^{-2}$ was collected from the sampling site, and maximum biomass was measured in August $\left(1544 \pm 356 \mathrm{~g}\right.$ [dry mass] $\mathrm{m}^{-2}$ ) (Fig. 1)

The difference between the macrophyte biomass in Lake Fertő and in Lake Kolon was significant both for submerged (2-way ANOVA; $\mathrm{F}=91.6 ; \mathrm{P}=0.011$ ) and emergent (2-way ANOVA; $\mathrm{F}=327.3 ; \mathrm{P}<0.001 ;$ Fig. 1) macrovegetation. The large difference between the emergent sites was a result of the smaller size of the Phragmites plants in Lake Fertö; at the peak of the growing season, the biomass of reed plants in Lake Kolon was 2.5-3 time higher than that of plants in Lake Ferto (42.3 \pm 6.0 and $14.8 \pm 1.6$, respectively) as a result of both the taller and larger diameter plants (Supplementary Fig. 2). Nevertheless, Phragmites plants at both sites had nearly identical numbers and relative biomass of green leaves, yet during senescence, Phragmites plants from Lake Fertő lost $55 \%$ of their leaf biomass, while plants from Lake Kolon lost 21\% (Supplementary Fig. 3). Further analysis showed that, except for nitrate content (Pearson: $r=0.976, P=0.025$ ), biomass accumulation did not correlate with any edaphic properties of the studied sites (Table 1) and was not related to the limnological properties of the sites (data not shown), probably because for the majority of parameters the lakes were similar with minor differences (Supplementary Tables 1-5).

BP at all sites showed a typical seasonal pattern, with low values in late autumn, at winter and the beginning of spring, and highest production between July and September (Fig. 2). BP of the submerged macrophyte dominated site in Lake Fertő (seasonal average $4.9 \pm 0.6 \mu \mathrm{g} \mathrm{C} 1^{-1} \mathrm{~h}^{-1}$ ) was significantly higher than that of Lake Kolon $(2.1 \pm 0.6 \mu \mathrm{g} \mathrm{C}$ $\mathrm{l}^{-1} \mathrm{~h}^{-1} ; 2$-way ANOVA $\mathrm{F}=11.0, \mathrm{P}=0.013$ ) (Fig. 2a). The emergent-dominated sites have high $\mathrm{BP}$ values with seasonal averages of $4.9 \pm 0.7$ and $3.6 \pm 0.5 \mu \mathrm{g} \mathrm{C} 1^{-1} \mathrm{~h}^{-1}$ at Lakes Fertő and Kolon, respectively, though this difference was not significant (Fig. 2a-way ANOVA F=2.3, P=0.169). BA in Lake Fertô and Lake Kolon were very similar, with maximal counts of $5.3 * 10^{6}$ and $7.0^{*} 10^{6}$ cells $\mathrm{ml}^{-1}$ respectively (2-way ANOVA, P >0.46; Fig. 2b).

At low BP and low BA the plant biomass was also low. Plant biomass peaked at intermediate heterotrophic bacterial production (Fig. 3) and heterotrophic bacterial abundance (Fig. 4). At heterotrophic bacterial production $5.6 \mu \mathrm{g}$ $\mathrm{C}^{-1} \mathrm{~h}^{-1}$ and heterotrophic bacterial abundance values of $5.3^{*} 10^{6}$ cells the macrophyte biomass peaked $\left(\sim 1.5 \mathrm{~kg} \mathrm{~m}^{-2}\right)$ (Figs. 3 and 4). At time of high BP $\left(>8 \mu \mathrm{g} \mathrm{C}^{-1} \mathrm{~h}^{-1}\right)$ and high BA $\left(>6.0 * 10^{6}\right.$ cells) had low macrophyte biomass (Figs. 3 and 4). GAM revealed that BP was not predicted by either macrophyte biomass or temperature. Bacterial abundance was significantly related to macrophyte biomass

Table 1 Pearson product moment correlation (coefficient $\mathrm{r}$ and significance P) between seasonal maximal biomass and seasonal nutrient average at the study site in Lakes Fertô and Kolon

\begin{tabular}{lllllll}
\hline & $\mathrm{NH}_{4}-\mathrm{N}$ & $\mathrm{NO}_{3}-\mathrm{N}$ & $\mathrm{TSN}$ & $\mathrm{TN}$ & $\mathrm{SRP}$ & \\
\hline $\mathrm{r}$ & -0.23 & 0.98 & 0.73 & 0.94 & 0.67 & 0.89 \\
$\mathrm{P}$ & 0.775 & 0.025 & 0.268 & 0.064 & 0.334 & 0.108 \\
\hline
\end{tabular}




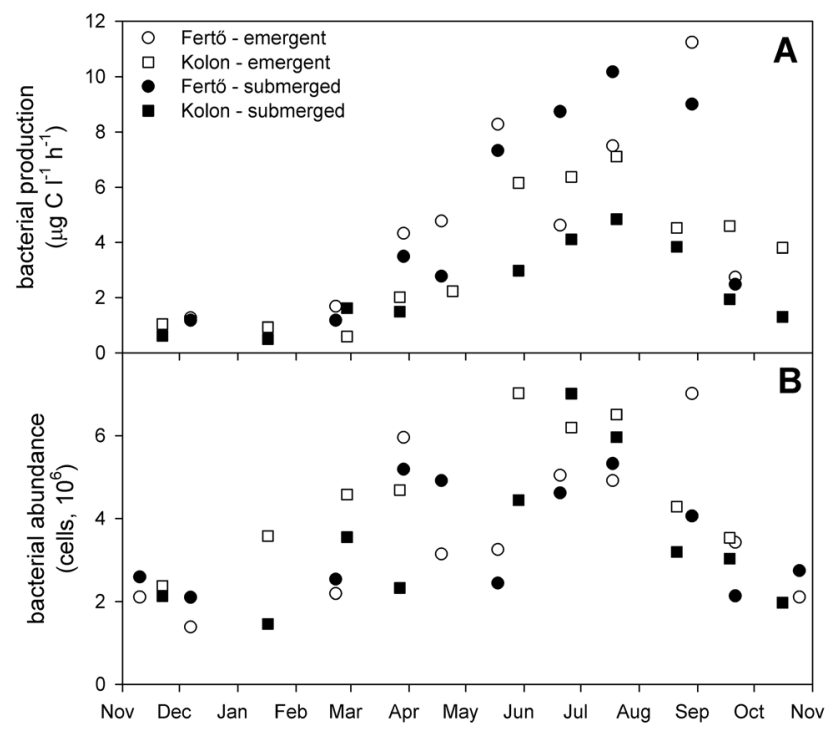

Fig. 2 Seasonal changes of major bacterial production (a) and bacterial abundance (b) in the submerged (black symbols) and emergent (white symbols) macrophytes stands of Lake Fertő (circle symbols) and Lake Kolon (square symbols)

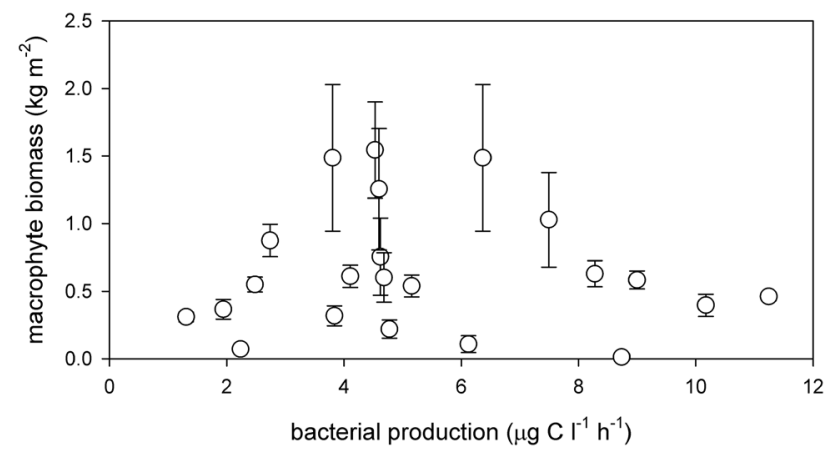

Fig. 3 Heterotrophic bacterial production and macrophyte biomass in the submerged and emergent macrophyte dominated sites of Lake Fertô and Lake Kolon

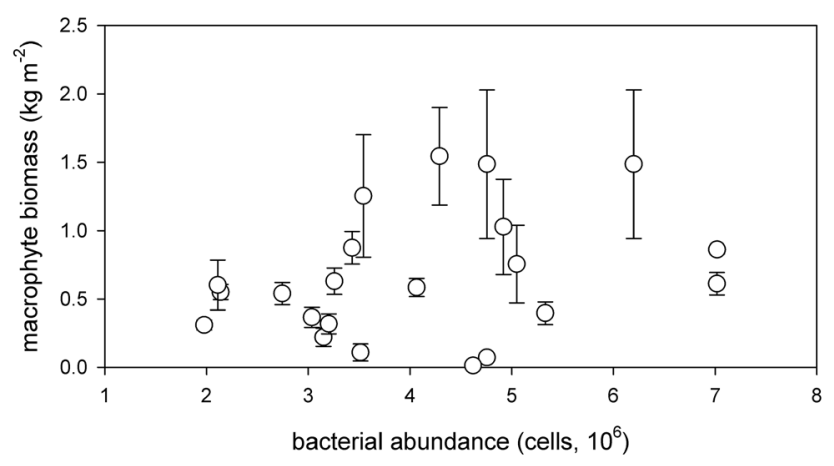

Fig. 4 Heterotrophic bacterial abundance and macrophyte biomass in the submerged and emergent macrophyte dominated sites of Lake Fertő and Lake Kolon $(p<0.05)$ but not temperature (Supplementary Table 6). Additional analysis showed some temporal and thermal relations between macrophytes biomass and bacteria activity/ abundance (Supplementary Figs. 4 and 5). Biomass accumulation rates also showed a relation to BP and BA (Fig. 5).

The original source of carbon for bacteria is the coloured dissolved organic matter coming from macrophytes (Fig. 6 and Supplementary Fig. 6.). Our data show that both the BP and the BA in warm (above annual average, Supplementary Table 1) waters correlated with CDOM content of the water (Pearson Product Moment Correlation $\mathrm{r}=0.63, \mathrm{P}=0.001$ and $r=0.536, P=0.010$, respectively; Fig. 6 ). The bacterial activity changed the chemistry and the $\mathrm{O}_{2}$ content of the sediment and the water column. The oxidation reduction potential (ORP) of the upper layer of the sediment in the second half of the summer correlated with both BP (Pearson Product Moment Correlation $\mathrm{r}=-0.70, \mathrm{P}=0.012$ ) and $\mathrm{BA}$ (Pearson Product Moment Correlation $\mathrm{r}=-0.66, \mathrm{P}=0.021$; Fig. 7). The anoxic ORP of the sediment was apparent throughout the season and at different depths (Supplementary Fig. 7), driving the oxygen content of the water column into the unsaturated zone (Supplementary Fig. 8).

\section{Discussion}

Littoral zones are important and very productive parts of aquatic ecosystems (Costanza et al. 1997; Ziegler et al. 2015). Due to the characteristics of the littoral zone (inundation, lack of grazing, etc.), the majority of the macrovegetation biomass will eventually become litter, which could be substantial (Duarte and Kalf 1986; Rooney and Kalff 2000; Windham 2001; Karunaratne et al. 2003; Tóth 2016). The average annual production of submerged and emergent patches at Lake Fertó and Lake Kolon was $\sim 0.5$ and $1.4 \mathrm{~kg}$ $\mathrm{m}^{-2}$ respectively. While no difference in the biomass accumulation of submerged macrophytes in Lakes Fertô and Kolon was shown, the above-ground production of Phragmites in Lake Kolon was higher than that in Lake Fertő (1.5 and $1.2 \mathrm{~kg} \mathrm{~m}^{-2} \mathrm{y}^{-1}$, respectively). Besides the difference in accumulated biomass, the seasonal dynamics of litter production in the Phragmites stands was different too; in Lake Fertő it started earlier (July) than in Lake Kolon (September). Moreover, in Lake Fertő this litter production was higher $\left(470 \mathrm{~g} \mathrm{~m}^{-2}\right)$ than in Lake Kolon $\left(346 \mathrm{~g} \mathrm{~m}^{-2}\right)$, which results in a substantial carbon accumulation and a possible explanation for higher BP rates in Lake Fertő.

Our data indicate that the macrophyte-derived organic matter (CDOM) affects planktonic heterotrophic bacterial production and bacterial abundance throughout the whole study period, although this relation becomes more significant at warmer water temperatures. In return, this bacterial activity and abundance has influence on the biomass 


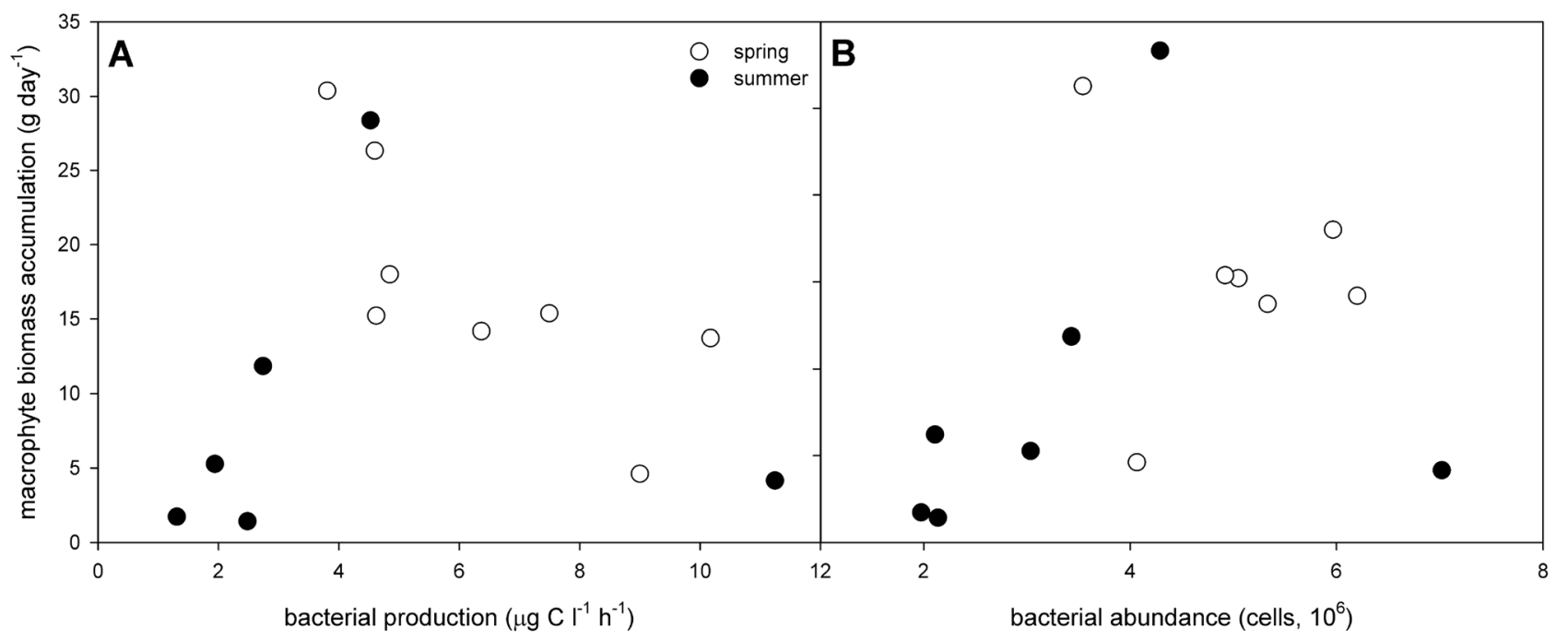

Fig. 5 Relation between bacterial production (a-nonlinear regression $\mathrm{R}=0.50, \mathrm{P}=0.200$ ), heterotrophic bacterial abundance (b-nonlinear regression $\mathrm{R}=0.54, P=0.121$ ) and the biomass accumulation rate at the studied sites. Correlation of bacterial production: spring-linear

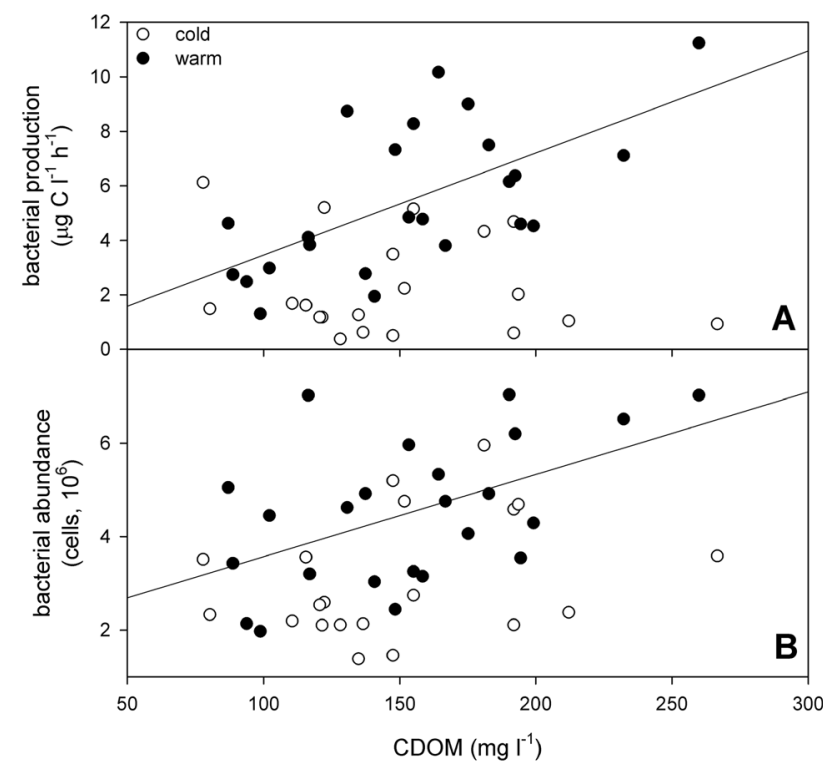

Fig. 6 Change of heterotrophic bacterial production (a), heterotrophic bacterial abundance (b) with the colour dissolved organic matter (CDOM) content of the water at studied sites in below (cold-white symbols) and above average (warm-black symbols) temperature waters of the studied sites. Pearson Product Moment Correlation $\mathrm{r}=0.63, \mathrm{P}=0.001$ and $\mathrm{r}=0.536, \mathrm{P}=0.010$, respectively

and biomass accumulation rates of macrophytes. At activities higher than $5.6 \mu \mathrm{g} \mathrm{C}^{-1} \mathrm{~h}^{-1}$ and bacterial abundance higher than $5.3 * 10^{6}$ cells the biomass of macrophytes could be affected and decrease by up to $50-60 \%$. It is also shown that bacterial activity in spring could negatively impact macrophyte growth rates. regression $\mathrm{R}=-0.74, \mathrm{P}=0.035$; summer - nonlinear regression: $\mathrm{R}=0.96, \mathrm{P}=0.022$. Correlation of bacterial abundance: spring-nonlinear regression $\mathrm{R}=0.97, \mathrm{P}=0.004$; summer- nonlinear regression $\mathrm{R}=0.14, \mathrm{P}=0.757$

In our study we showed that increase in the number of heterotrophic bacteria and increase in their activity mainly due to increased litter decomposition resulted in unfavourable conditions, mostly by decreasing the ORP to anoxic conditions as previously described (Tóth 2016). Although some morphological, physiological and physical (Armstrong and Armstrong 1990; Amsberry et al. 2000) factors help macrophytes to survive these adverse conditions, extremely low ORP (oxygen depletion) eventually could not be tolerated by majority of macrophytes.

We were unable to relate the observed differences in macrophyte biomass to any measured limnological or chemical factor, and found that the bacteriological data do correlate with biomass accumulation, though not in a linear way. Similar results (i.e., plant biomass was positively related to bacterial activity), have also been observed in other cases (López et al. 1995; Isaksen and Finster 1996; Boschker et al. 2000). The increased activity and more abundant microbiota, change the oxygenation of area, implying accompanying biogeochemical changes, such as increased volatile fatty acid and sulphide pools (Findlay et al. 1986; Reitner et al. 1999; Jeppesen et al. 2002; Rooney and Kalff 2003), which might directly or indirectly affect plant growth.

Besides the absolute amount, the composition of the litter could affect bacterial activity and quantity. Phragmites litter, due its slow rate of decay, could cover the sediment surface for a long time, while submerged macrophyte litter will decompose significantly faster. $\mathrm{N}$ and $\mathrm{P}$ contents of the decomposing litter have a significant effect on bacterial activity (Güsewell and Gessner 2009), thus submerged macrophytes due to their higher $\mathrm{N}$ and $\mathrm{P}$ contents decompose 


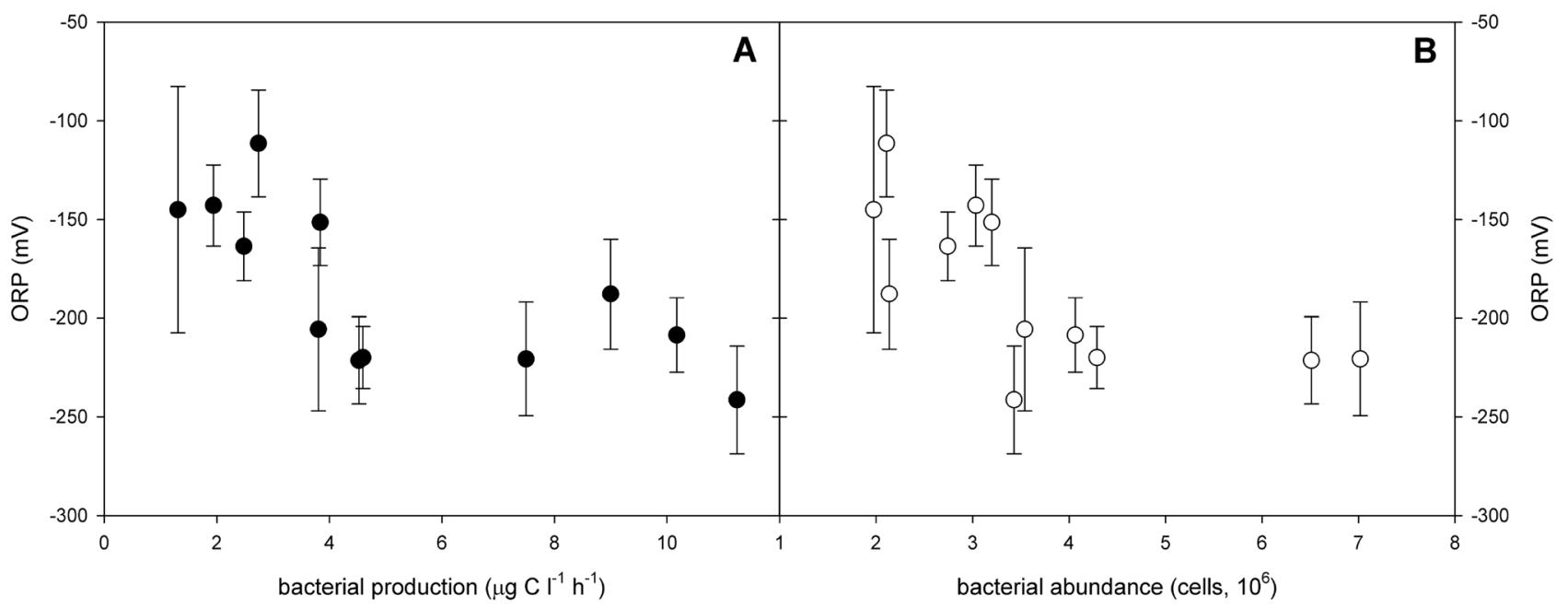

Fig. 7 Relation between bacterial production (a), heterotrophic bacterial abundance $(\mathbf{b})$ and the oxidation reduction potential of the upper $10 \mathrm{~cm}$ of the sediment at the studied sites near the population climax

significantly faster, while the decay rate of emergent macrophytes is lower, due to their extremely limited $\mathrm{N}$ and $\mathrm{P}$ (Enríquez et al. 1993; Windham and Lathrop 1999; Güsewell and Gessner 2009). Moreover, since the stems and leaves of Phragmites have different decay rates (Windham 2001; Balogh et al. 2006), the composition of the litter could also affect activity of the microbiota. In our study, in Lake Fertó the foliar litter production was higher $\left(\sim 230 \mathrm{~g} \mathrm{~m}^{-2}\right)$ than in Lake Kolon $\left(66 \mathrm{~g} \mathrm{~m}^{-2}\right)$, which results in a higher, easy to access carbon pool and could be a possible explanation for higher heterotrophic bacterial production rates in Lake Fertô.

In conclusion, our data showed that bacterial activity could affect macrophyte growth, both directly and indirectly through changing the oxygenation of the sediment and water. Over specific bacterial activity and abundance macrophyte biomass accumulation is showing their multifaceted relationship: macrophytes are not only the most significant carbon source for the bacteria, but are also a competing organism.

Acknowledgements This research was supported by grants National Research, Development and Innovation Office-NKFIH, K-116666 and National Research, Development and Innovation Office-NKFIH, KH-129505 of the Hungarian National Research, Development and Innovation Office. The authors are grateful to Stephanie C. J. Palmer for her help with the English of the text.

Funding Open access funding provided by ELKH Centre for Ecological Research.

Open Access This article is licensed under a Creative Commons Attribution 4.0 International License, which permits use, sharing, adaptation, distribution and reproduction in any medium or format, as long as you give appropriate credit to the original author(s) and the source, provide a link to the Creative Commons licence, and indicate if changes
(July-August-September). Pearson product moment correlations: a$\mathrm{r}=-0.70, \mathrm{P}=0.012 ; \mathbf{b}-r=-0.66, P=0.021$

were made. The images or other third party material in this article are included in the article's Creative Commons licence, unless indicated otherwise in a credit line to the material. If material is not included in the article's Creative Commons licence and your intended use is not permitted by statutory regulation or exceeds the permitted use, you will need to obtain permission directly from the copyright holder. To view a copy of this licence, visit http://creativecommons.org/licenses/by/4.0/.

\section{References}

Balogh V, Présing K, Vörös M, Tóth LN (2006) A study of the decomposition of reed (Phragmites australis) as a possible source of aquatic humic substances by measuring the natural abundance of stable carbon isotopes. Int Rev Hydrobiol 91(1):15-28

Amsberry L, Baker MA, Ewanchuk PJ, Bertness MD (2000) Clonal integration and the expansion of Phragmites australis. Ecol Appl 10:1110-1118

Armstrong J, Armstrong W (1990) Light-Enhanced Convective Throughflow Increases Oxygenation in Rhizomes and Rhizosphere of Phragmites australis (Cav.) Trin. ex Steud. New Phytol 114:121-128

Armstrong J, Armstrong W, Putten WH (1996) Phragmites die-back: bud and root death, blockages within the aeration and vascular systems and the possible role of phytotoxins. New Phytol 133:399-414

Armstrong J, Armstrong W (1999) Phragmites die-back: toxic effects of propionic, butyric and caproic acids in relation to $\mathrm{pH}$. New Phytol 142(2):201-217

Azam F, Fenchel T, Field JG, Gray JS, Meyer-Reil LA, Thingstad F (1983) The ecological role of water-column microbes in the sea. Mar Ecol Prog Ser 10:257-263

Azam F, Smith D, Steward G, Hagström Å (1994) Bacteria-organic matter coupling and its significance for oceanic carbon cycling. Microb Ecol 28:167-179

Barko J, Smart R (1983) Effects of organic matter additions to sediment on the growth of aquatic plants. J Ecol 71(1):161-165 
Barko JW, Smart RM (1986) Sediment-related mechanisms of growth limitation in submersed macrophytes. Ecology 67:1328-1340

Barko JW, Gunnison D, Carpenter SR (1991) Sediment interactions with submersed macrophyte growth and community dynamics. Aquat Bot 41:41-65

Boschker HTS, Wielemaker A, Schaub BEM, Holmer M (2000) Limited coupling of macrophyte production and bacterial carbon cycling in the sediments of Zostera spp. meadows. Mar Ecol Prog Ser 203:181-189

Carpenter SR (1981) Submersed vegetation: an internal factor in lake ecosystem succession. Am Nat 118:372-383

Cole JJ, Carpenter SR, Kitchell JF, Pace ML (2002) Pathways of organic carbon utilization in small lakes: Results from a whole-lake $13 \mathrm{C}$ addition and coupled model. Limnol Oceanogr 47:1664-1675

Costanza R, d'Arge R, De Groot R et al (1997) The value of the world's ecosystem services and natural capital. nature 387:253

Cuthbert ID, Del Giorgio P (1992) Toward a standard method of measuring color in freshwater. Limnol Oceanogr 37:1319-1326

Duarte CM, Kalf J (1986) Littoral slope as a predictor of the maximum biomass of submerged macrophyte communities1y2. Limnol Ocean 31:1072-1080

Duarte CM, Prairie YT (2005) Prevalence of heterotrophy and atmospheric $\mathrm{CO} 2$ emissions from aquatic ecosystems. Ecosystems 8:862-870

Elliott RJ, Porter AG (1971) A rapid cadmium reduction method for the determination of nitrate in bacon and curing brines. Analyst 96:522-527

Enríquez S, Duarte CM, Sand-Jensen KAJ (1993) Patterns in decomposition rates among photosynthetic organisms: the importance of detritus C: N: P content. Oecologia 94:457-471

Findlay S, Carlough L, Crocker MT et al (1986) Bacterial growth on macrophyte leachate and fate of bacterial production. Limnol Oceanogr 31:1335-1341

Gales ME, Julian EC, Kroner RC (1966) Method for quantitative determination of total phosphorus in water. J Am Water Works Assoc 1363-1368

Gasol JM (1999) How to measure bacterial activity and production with the uptake of radiolabeled leucine. http://www.cmima.csic. ed/pub/gasol/Manials/ProdBact/Leucine.htm

Güsewell S, Gessner MO (2009) N: P ratios influence litter decomposition and colonization by fungi and bacteria in microcosms. Funct Ecol 23:211-219

Isaksen MF, Finster K (1996) Sulphate reduction in the root zone of the seagrass Zostera noltii on the intertidal flats of a coastal lagoon (Arcachon, France). Mar Ecol Prog Ser 187-194

Iwamura T, Nagai H, Ichimura SE (1970) Improved methods for determining contents of chlorophyll, protein, ribonucleic acid, and deoxyribonucleic acid in planktonic populations. Int Rev Gesamten Hydrobiol Hydrogr 55:131-147

Jeppesen E, Søndergaard M, Christoffersen K et al (2002) Cascading trophic interactions in the littoral zone: an enclosure experiment in shallow Lake Stigsholm, Denmark. Fundam Appl Limnol 153:533-555

Jones SE, Newton RJ, McMahon KD (2009) Evidence for structuring of bacterial community composition by organic carbon source in temperate lakes. Environ Microbiol 11:2463-2472

Jonsson A, Meili M, Bergström A-K, Jansson M (2001) Whole-lake mineralization of allochthonous and autochthonous organic carbon in a large humic lake (Örträsket, N. Sweden). Limnol Oceanogr 46:1691-1700

Karunaratne S, Asaeda T, Yutani K (2003) Growth performance of Phragmites australis in Japan: influence of geographic gradient. Environ Exp Bot 50:51-66
Kirchman D, K'nees E, Hodson R (1985) Leucine incorporation and its potential as a measure of protein synthesis by bacteria in natural aquatic systems. Appl Environ Microbiol 49:599-607

Koch EW (2001) Beyond light: physical, geological, and geochemical parameters as possible submersed aquatic vegetation habitat requirements. Estuaries 24:1-17

Laanbroek HJ (1990) Bacterial cycling of minerals that affect plant growth in waterlogged soils: a review. Aquat Bot 38:109-125

Lacoul P, Freedman B (2006) Environmental influences on aquatic plants in freshwater ecosystems. Environ Rev 14:89-136

Lindström ES (2000) Bacterioplankton community composition in five lakes differing in trophic status and humic content. Microb Ecol 40:104-113

Lindström ES, Kamst-Van Agterveld MP, Zwart G (2005) Distribution of typical freshwater bacterial groups is associated with $\mathrm{pH}$, temperature, and lake water retention time. Appl Environ Microbiol 71:8201-8206

López NI, Duarte CM, Vallespinós F et al (1995) Bacterial activity in NW Mediterranean seagrass (Posidonia oceanica) sediments. J Exp Mar Biol Ecol 187:39-49

Mackereth FJH, Heron J, Talling JF (1978) Water analysis: some revised methods for limnologists. Freshwater Biological Association, Ambleside

Mádl-Szőnyi J, Tóth J (2009) A hydrogeological type section for the Duna-Tisza Interfluve, Hungary. Hydrogeol J 17:961-980

Márkus I, Király G, Börcsök Z (2008) A Fertő tó magyarországi nádasainak minősítése és osztályozása (Qualification and classification of the reed stands of Lake Fertő.). ÉDUKÖVIZIG-North Danube Basin Water Authority, Sopron

Márkus I, Király G (2012) A Fertő magyarországi nádasainak minősítése, osztályozása és térképezése (Qualification, classification and mapping of the reed stands of the Hungarian part of Lake Fertő). In: Monografikus tanulmányok a Fertő és a Hanság vidékéről. Monographic studies of Lake Fertő and Hanság area), Budapest

Menzel DW, Corwin N (1965) The measurement of total phosphorus in seawater based on the liberation of organically bound fractions by persulfate oxidation. Limnol Oceanogr 10:280-282

Middelburg JJ, Levin LA (2009) Coastal hypoxia and sediment biogeochemistry. Biogeosciences 6:1273-1293

Newell BS, Morgan B, Cundy J (1967) The determination of urea in seawater. J Mar Res 25:201-202

Newton RJ, Jones SE, Eiler A et al (2011) A guide to the natural history of freshwater lake bacteria. Microbiol Mol Biol Rev 75:14-49

Odum HT (1956) Primary production in flowing waters. Limnol Oceanogr 1:102-117

Porter KG, Feig YS (1980) The use of DAPI for identifying and counting aquatic microflora. Limnol Oceanogr 25:943-948

Reddy KR, DeLaune RD (2008) Biogeochemistry of wetlands: science and applications. CRC press

Reitner B, Herzig A, Herndl GJ (1999) Dynamics in bacterioplankton production in a shallow, temperate lake (Lake Neusiedl, Austria): evidence for dependence on macrophyte production rather than on phytoplankton. Aquat Microb Ecol 19:245-254

Richey JE, Melack JM, Aufdenkampe AK et al (2002) Outgassing from Amazonian rivers and wetlands as a large tropical source of atmospheric $\mathrm{CO} 2$. Nature 416:617

Rooney N, Kalff J (2000) Inter-annual variation in submerged macrophyte community biomass and distribution: the influence of temperature and lake morphometry. Aquat Bot 68:321-335

Rooney N, Kalff J (2003) Submerged macrophyte-bed effects on watercolumn phosphorus, chlorophyll a, and bacterial production. Ecosystems 6:797-807

Schauer M, Kamenik C, Hahn MW (2005) Ecological differentiation within a cosmopolitan group of planktonic freshwater bacteria 
(SOL cluster, Saprospiraceae, Bacteroidetes). Appl Environ Microbiol 71:5900-5907

Schindler DE, Scheuerell MD (2002) Habitat coupling in lake ecosystems. Oikos 98:177-189

Schmidt J, Csaplovics E (2010) Mapping the Austrian reed bed of Lake Neusiedl by means of airborne optical scanner imagery. In: International Symposium on Advanced Methods of Monitoring Reed Habitats in Europe, Illmitz, AT

Simon M, Azam F (1989) Protein content and protein synthesis rates of planktonic marine bacteria. Mar Ecol Prog Ser. Oldendorf 51(3):201-213

Sommaruga R, Casamayor EO (2009) Bacterial 'cosmopolitanism' and importance of local environmental factors for community composition in remote high-altitude lakes. Freshw Biol 54:994-1005

Tóth VR (2016) Reed stands during different water level periods: physico-chemical properties of the sediment and growth of phragmites Australis of Lake Balaton. Hydrobiologia 778:193-207. https:// doi.org/10.1007/s10750-016-2684-z

Tóth VR, Endre G, Kovács S, Présing M, Horváth H (2017) Morphological and Genetic Variability of Myriophyllum spicatum in Different Shallow Water Bodies of Hungary. Wetlands 37(2):351362. https://doi.org/10.1007/s13157-016-0875-z

Tranvik LJ, Downing JA, Cotner JB et al (2009) Lakes and reservoirs as regulators of carbon cycling and climate. Limnol Oceanogr 54:2298-2314
Wetzel RG (1995) Death, detritus, and energy flow in aquatic ecosystems. Freshw Biol 33:83-89

Windham L, Lathrop RG (1999) Effects of Phragmites australis (common reed) invasion on aboveground biomass and soil properties in brackish tidal marsh of the Mullica River, New Jersey. Estuaries Coasts 22:927-935

Windham L (2001) Comparison of biomass production and decomposition between Phragmites australis (common reed) and Spartina patens (salt hay grass) in brackish tidal marshes of New Jersey, USA. Wetlands 21:179-188

Yannarell AC, Triplett EW (2005) Geographic and environmental sources of variation in lake bacterial community composition. Appl Environ Microbiol 71:227-239

Zeder M, Kohler E, Zeder L, Pernthaler J (2011) A novel algorithm for the determination of bacterial cell volumes that is unbiased by cell morphology. Microsc Microanal 17:799-809

Ziegler JP, Solomon CT, Finney BP, Gregory-Eaves I (2015) Macrophyte biomass predicts food chain length in shallow lakes. Ecosphere 6:1-16

Publisher's Note Springer Nature remains neutral with regard to jurisdictional claims in published maps and institutional affiliations. 